\title{
Juan C. Onetti: el poder de las imágenes
}

¿Cómo leer una literatura que hace de la experiencia visual su principio constitutivo? ¿Qué postulación de la realidad deja suponer el encuentro de la escritura y la imagen? Más precisamente, ¿qué procedimientos interpretativos requeriría una escritura que al ofrecerse como "visión" más o menos mediada de un paisaje exterior desdibuja las fronteras entre lo referencial y lo imaginario? Siguiendo los lineamientos teóricos de la hermenéutica crítica (Ricoeur), método que toma en consideración la subjetividad y dimensión ontológica comprometida en la interpretación y la complementa con el análisis estructural de los textos, este trabajo analiza la funcionalidad de la imagen en la poética de Juan C. Onetti (1909-1994). Dos de sus cuentos, "Historia del caballero de la rosa y de la virgen encinta que vino de Liliput" (1956) y "El álbum" (1953), permitirán examinar la operatividad del prejuicio en relación a las expectativas de sentido abiertas por la imagen y el concepto de mímesis en una trama narrativa donde la enunciación importa más que el enunciado.

A Natalia Brizuela

Volver a leer (o seguir leyendo) a Onetti en una época que hace hincapié en el giro visual de la cultura es reconocer una poética muy actual que pone de manifiesto el predominio de la imagen y, a la vez, su carácter profundamente inestable. Lejos de la idea platónica que devalúa la representación por ser copia infiel de la cosa real, Onetti, perseguidor del hecho estético, funda su literatura sobre la belleza y los equívocos de la imagen. En el origen siempre hay algo que se ve, por lo común una figura formada por elementos heterogéneos que lleva a pensar en la complejidad de las apariencias y amenaza extraviar al lector en el caudal de historias que suscita. Es claro que la imagen no exonera a Onetti del acto narrativo ni, menos aún, presenta un obstáculo a lo que, en reconocimiento de un moderado espíritu barroco, ha sido llamada la "realidad soberana" (Saer 239) de su ficción. Marca genética de esta escritura, la relación con lo visual recuerda la intricación, pero también la irreductibilidad de la escritura y la imagen. ${ }^{1}$ Dicho de otra manera y para ahondar en las consecuencias de esto, se postula una dialéctica donde el texto y su exterioridad - lo 
imaginario y lo real, lo mismo y lo otro, los distintos parámetros temporales - pierden su carácter exclusivo.

Hay en esta poética un principio constructivo reconocible desde los primeros relatos. Escritor eminentemente visual, Onetti hace explícito en El pozo (1939) el vínculo que existe entre los sueños y la narración que ellos motivan hasta dibujar "la historia de un alma" (50). Las imágenes oníricas son la promesa y la exigencia de las formas donde aguarda la belleza hasta constituir la materia misma de la escritura. ${ }^{2}$ Allí está el núcleo y la razón de ser del relato: una belleza sin finalidad cuya literaturización sólo puede producirse a través de un idioma que está en espera de su creación. Un idioma construido a partir de imágenes, cuyo sentido no acaba nunca de revelarse y donde se cifraría el hecho estético. ${ }^{3}$

Partiendo de estas bases, me propongo indagar en la literatura de Onetti la fuerza creativa de lo visual y la respuesta que suscita en la recepción. Me interesa destacar, sobre todo, su intervención en el dominio de la mímesis - el modo en que las imágenes operan respecto a la creencia y su incidencia en una poética que parece restituir una forma antigua, mágica, de relacionarse con las cosas y entender el mundo. Desde luego, esto no implica que Onetti pase por alto el prejuicio ni el acto de resemantizar las imágenes por parte de aquellos que las reciben. Por el contrario, como los filósofos de la hermenéutica ontológica (Heidegger y, sobre todo, Gadamer), sabe que el prejuicio es una consecuencia de nuestro anclaje en una tradición y lo convierte en factor de intensidad y tensión narrativa. ${ }^{4}$

La mención a la tradición debe ser precisada. Entiendo este término no sólo como marco de referencia y criterio clasificatorio que en Onetti, así como en cualquier otro autor, hablaría de continuidades y rupturas con la literatura anterior - en este caso, el proyecto de alejarse del realismo u otro acercamiento edificante a la literatura, que se concibe como un campo autónomo -, sino además como horizonte de expectativas de sentido inscrito en la trama misma de los textos. Como intentaré mostrar en mi análisis, la remisión a una tradición toma en Onetti la forma de un juego narrativo que activa una serie de prejuicios, de falsas creencias, y dicta a las historias un final engañoso. ${ }^{5}$

De este modo, el sentido se vuelve para el lector, quien debe refigurar el texto, una experiencia de la indeterminación. Tanto en el interior del espacio ficcional como de cara a su exterior o recepción, el narrador onettiano supone una comunidad interpretativa sobre la que crece la ambigüedad para afirmarse, por último, un entendimiento, éxito o derrota, refractario a toda explicación. ${ }^{6}$ Cualquier obra de la saga de Santa María podría corroborarlo; recuerdo el camino que lleva del firme, colectivo, 
saber inicial en Para una tumba sin nombre - "Todos nosotros, los notables, los que ... sabemos cómo es un entierro en Santa María..." (987) - a la confesión de Díaz Grey que cierra este relato hecho de tantas historias o, mejor, de tantas versiones de una misma historia:

Y, más o menos, esto era todo lo que yo tenía después de las vacaciones. Es decir, nada; una confusión sin esperanza, un relato sin final posible, de sentidos dudosos, desmentido por los mismos elementos de que yo disponía para formarlo. Personalmente, sólo había sabido del último capítulo, de la tarde calurosa en el cementerio. Ignoraba el significado de lo que había visto, me era repugnante la idea de averiguar y cerciorarme. (1045)

Y también quisiera recordar Los adioses, otra novela corta construida enteramente sobre los prejuicios que alimentan la intriga. Como es común en Onetti, se narra en ella la llegada de alguien ajeno a la comunidad que atrae las miradas y sobre quien se tejen versiones infructuosas o definitivamente erróneas. Se trata de un hombre que escoge un pueblo de las sierras de Córdoba para curarse de la tuberculosis, motivando desde un principio un número de diagnósticos que rebasan lo estríctamente médico. ${ }^{7}$ Es de notar que este hombre, al igual que otros náufragos de Onetti, ofrece una complejidad difícil de discernir que ensancha la distancia con la comunidad y genera el misterio necesario a toda narración. ${ }^{8}$ Transcurre así una literatura de la sospecha que incita a la búsqueda hermenéutica.

Flota en la literatura de Onetti una burla no comprendida del todo; una situación equívoca, trama hecha de creencias falsas que crece hasta involucrar al lector. Aunque la falsedad de dichas creencias es finalmente revelada, la lógica que rige la conducta de los personajes y sus intrigas, así como el sentido de lo visto, permanece en una zona de sombra. Es lo que ocurre en Para una tumba sin nombre con las distintas versiones sobre la historia de Rita y, también, en Los adioses con las conjeturas realizadas en torno a la identidad de las dos mujeres que visitan al hombre enfermo y su verdadero lazo con este. Nada se explica. Aunque quizá, para mayor precisión, debería decirse que el texto redefine lo que entendemos por explicación. Jacques Rancière dice algo útil al respecto en su libro Figuras de la historia:

Explicar quiere decir, en efecto, dos cosas muy distintas. Puede ser proporcionar el sentido de una escena, la razón de una actitud o de una expresión. Pero puede ser también, según la etimología de la palabra, dejar que se despliegue la plenitud plegada en su simple presencia. Cortando el hilo de toda razón, se deja la escena, la 
actitud, el rostro, al mutismo que les confiere un doble poder: detener la mirada en esa evidencia de existencia ligada a la ausencia misma de razón, desplegar dicha evidencia como virtualidad de un mundo posible. (24)

Tenemos así la escritura y la lectura del texto literario como prácticas inacabadas, opuestas a los procesos de la razón y otras formas de explicación extratextual. Liberada de una comprensión lógica, la obra promete sentidos de orden estético y, por lo tanto, intuitivos. Cualquier intento de traducción - quiero decir, de explicación con criterios externos a la obra - haría peligrar dicho orden. Nuevamente, nos encontramos ante una narrativa que no busca dilucidarse a través del eje explicativo. La comprensión que emerge de ella remite a nuevas imágenes que, paradójicamente, profundizan el enigma de la mirada inicial. En palabras de Rancière: "un pacto con lo insignificante" (25).

Comprender las razones que dan vigencia a la poética de Onetti es una de las motivaciones de este trabajo. ¿Qué hace tan profundamente actual una literatura en la que, al margen de su efecto sobre una imaginación espoleada por imágenes, pasa poco o casi nada y, sobre eso que pasa, desconocemos el sentido? Y sin embargo, no me parece pertinente hablar de escepticismo ni de un nihilismo fundamental. Pues se entiende que la imagen no es antitética a la verdad, sino que a diferencia del saber que brinda el razonamiento abstracto requiere la actuación de los sentidos para ser intuida. Es esta promesa de comprensión o experiencia de la indeterminación, ya que llevada a cabo al margen de la atención referencial y de los contenidos conjeturales, lo que incita a seguir leyendo y ratifica en cada intento la actualidad de esta literatura.

De acuerdo con uno de los postulados básicos de la hermenéutica, la literatura de Onetti supone una circularidad entre el texto y la interpretación; un retorno a aquel en busca de un sentido presente e intransferible. De aquí que su valor no dependa de una explicación del sentido que, en caso de ser determinada por factores externos, ignoraría el carácter continuo, renovable y siempre vigente, de la interpelación estética.

PREJUICIOS

Para ilustrar lo que llamo experiencia de la indeterminación, analizaré un cuento de 1956, titulado "Historia del caballero de la rosa y de la virgen encinta que vino de Liliput". Como suele suceder en Onetti, un narrador que hace uso de un plural sociativo asume la enunciación, encarnando un grupo de notables que comparte un saber o, más precisamente, una creencia que se transmuta en una forma de mirar. El comienzo, que enlaza 
el relato al advenimiento de la noche, sugiere prestar atención al sentido de las imágenes, supeditándolo a conjeturas que se quieren despreocupadas e inciertas:

En el primer momento creímos los tres conocer al hombre para siempre, hacia atrás y hacia adelante. Habíamos estado tomando cerveza tibia en la vereda del Universal, mientras empezaba una noche de fines de verano ...

-Vean - susurró Guiñazú, retrocediendo en la silla de hierro -. Miren, pero no miren demasiado. Por lo menos, no miren con avidez y, en todo caso, tengan la prudencia de desconfiar. Si miramos indiferentes, es posible que la cosa dure, que no se desvanezcan, que en algún momento lleguen a sentarse, a pedir algo al mozo, a beber, a existir de veras. (1249)

El relato se inicia, pues, con la llegada de algo insólito, falsamente familiar, que atrae la mirada. Se trata de una pareja de bailarines, dos seres caídos de no se sabe qué planeta lejano, cuya presencia distrae a los sanmarianos de su aburrimiento y sus vidas mediocres. Las preguntas sobre el origen de la pareja y la razón de su estancia en Santa María constituyen la trama de este cuento y sustentan la duda más allá del desmentido final que ofrece la narración sin develación del misterio. Insisto en esto: lo que importa es la visión que desencadena el proceso de narrar. Un modo de mirar que recuerda la semántica compleja del objeto y convierte al lector en un hermeneuta de la sospecha. Se anhela dar con "la clave de la pareja" hallar "definiciones y adjetivos" (1255) que logren acercarla -, pero sin olvidar que la atención ha de ser dirigida, no sólo hacia la representación, sino también hacia las estructuras del entendimiento. Dicho de otro modo, se subraya la importancia de alcanzar una experiencia de las formas o saber estético. Guiñazú, cuyo nombre alude a lo ocular, un guiño que es señal de complicidad con el lector, llama a profundizar la mirada y poner a prueba los modos de creer: "Pueden seguir mirando - permitió Guiñazú -, pero no hablen todavía. Acaso sean tal como los vemos, acaso sea cierto que están en Santa María" (1250). La escritura de Onetti se desenvuelve a partir de ese propósito: hacer "existir" la visión, vertiéndola en una mímesis que haga verosímil la escena e incite a su interpretación. Claro está, el sentido resultante no se referirá a una totalidad unívoca y perdurable, sino por el contrario a algo cuya suerte quedará comprometida en el instante mismo de la recepción: "Ya cayó una gota dijo Guiñazú -. La lluvia estuvo amenazando desde la madrugada y va a empezar justo ahora. Va a borrar, a disolver esto que estábamos viendo y que casi empezábamos a aceptar. Nadie querrá creernos" (1250). 
En su multiplicación de marcas autorreferenciales el texto hace visible su lógica interna, destacando la relación entre imagen y escritura. ${ }^{9}$ Sin ignorar la heterogeneidad respectiva, se trataría de alcanzar en la escritura la inmediatez de la imagen, su veracidad fugaz y paradójica. Ya he dicho que la visión tiene por objeto un conjunto de elementos dispares $y$ contradictorios; a decir del narrador, "[e]l hombre era de muchas maneras y éstas coincidían, inquietas y variables, en el propósito de mantenerlo vivo, sólido, inconfundible" (1250). No menos desconcertante e inestable es la figura de la mujer, tal como lo indica desde el título el oxímoron (virgen encinta) que la nombra. ${ }^{10} \mathrm{Y}$ sin embargo, pareciera afirmar Onetti en un encuentro inesperado con Santo Tomás, que sin imagen no hay creencia; aunque convendría agregar que, si bien se debe ver para creer, la imagen sola, sin relato, resulta irrelevante. Si bien ella es la motivación de la escritura, el punto de arranque de la narración de ningún modo puede ser sustitutiva."

Hasta aquí, la imagen como motivación estética. Puede decirse que se trata siempre de un "prólogo" (el núcleo de un relato) sobre el que luego la escritura ofrecerá distintas versiones y aludirá a otros tantos significados. La pareja de recién llegados, luego de unas semanas en las que define su distancia justa con la comunidad, recala en la casa de Doña Mina, un personaje de reminiscencia faulknereana que la acoge atraída, seguramente, por el misterio y la alegría poco común de su presencia. Guiñazú retiene el enigma y deliberado juego de sospechas que despierta la amistad entre la vieja rica patricia y los forasteros: "Los ojos de la vieja me miraban contándome algo, seguros de que yo no era capaz de descubrir de qué se trataba; burlándose de mi incomprensión y también, anticipadamente, de lo que pudiera comprender equivocándome. Los ojos, estableciendo por un instante conmigo una complicidad despectiva" (Onetti 1264).

Alrededor de la pareja, instalada ya en Las Casuarinas y con un protagonismo creciente, se va tejiendo el relato de su otredad; una investigación sobre su identidad, intención y signo que, por cierto, contiene una pregunta sobre los mismos observadores. ${ }^{12} \mathrm{Y}$ aunque la pareja aporta poco en lo inmediato, motiva un proceso de fabulación que no está reñido con la mímesis o verdad de la ficción.

Alguno, cualquiera de nosotros, mencionaba a la pareja, y los demás íbamos aportando lo que podíamos, sin preocuparnos de que fuera poco o mucho, como verdaderos amigos.

Bailan, son bailarines, eso puede afirmarse, y no es posible decir otra cosa, si hemos jurado decir solamente verdades para descubrir o formar la verdad. Pero no 
hemos jurado nada. De modo que las mentiras que pueda acercar cada uno de nosotros, siempre que sean de primera mano y que coincidan con la verdad que los tres presentimos, serán útiles y bienvenidas. (1253)

Recordando la categorización aristotélica, Onetti establece una jerarquía en la que lo "imaginativo" supera la intención realista, sin excluir por ello un conocimiento de lo real o restitución comprensiva de lo que fue a partir de la ficción. Este acercamiento a la realidad o mímesis se funda sobre imágenes, eikónes, que desafían la comprensión intelectual (Sinnott xxi). En este sentido, he creído necesario pensar el recurso a la imagen en Onetti como el núcleo productor de un distintivo modo de narrar.

Retomo los pasos de la historia. Toda Santa María sabe que poco antes de celebrar su último cumpleaños, junto a la inevitable pareja de bailarines, doña Mina ha llamado al escribano Ferragut para modificar su testamento. Este dato inquieta a la comunidad. Al morir la vieja, los notables que ocupan el primer plano de la ficción, así como el resto del pueblo, pueden suponer ya sin tropiezos y equivocadamente, "sin más prueba que la emporcadora experiencia" (1269), que la riqueza por heredar ha sido transferida a la pareja de indiscutibles simuladores. Pero como se sabrá muy pronto, el testamento no contiene lo esperado y limita la herencia a una suma de quinientos pesos, dinero apenas suficiente para alimentar el perro incontinente de la difunta que también forma parte de los bienes dejados al caballero de la rosa y su mujer. Se llega así al clímax burlesco del relato. ${ }^{13}$

Es necesario agregar que no sólo el testamento desmiente lo que todos han creído mal, sino que también, y más importante aún, dicha creencia se deshace en pedazos ante el acto inexplicable con que el caballero de la rosa concluye este nuevo fragmento de la saga de Santa María. Pues es sabido que este convierte hasta el último centavo de la herencia en flores que, una vez arrojadas al pie de la tumba de doña Mina, ofrecen una imagen última que sumerge la historia en un paradójico misterio: "Y nada más hasta el fin, hasta la construcción exasperada del monumento vegetal que da interés a esta historia y la despoja de sentido. Nada realmente importante hasta la pira multicolor y jugosa, abrumadora, de intención desconocida, quemada en tres días por la escarcha de mayo" (1264-1265).

Esta nueva imagen - una pira de flores quemada por la escarcha - hace del relato un desafío semántico que, pese a la incertidumbre colectiva que se declara en la última línea respecto a la conducta de los protagonistas "lo que nosotros no pudimos saber nunca con certeza" (1271) -, no excluye una forma de comprensión o, por lo menos, el inicio de un camino que lleva hacia ella. Lo significativo nos llega a través de un idioma 
"desconocido" (1265), figurativamente rico, que permanece en el terreno de lo indeterminado y frustra cualquier intento de explicar. Así es el idioma que Doña Mina obsequia a su huésped en el momento supremamente indefinido de la muerte:

Personalmente [dice este], creo que estaba disputándose algo con una amiga de la juventud. Y después de unos diez minutos de murmullo vertiginoso se hizo indudable que la amiga, una niña casi, estaba siendo derrotada y que ella, Doña Mina, iba a quedarse para siempre con el atardecer glicinoso y jazminoso, con el hombre de párpados lentos, rizado, un bastoncito de jacarandá en la axila. Por lo menos, fue eso lo que entendí y sigo creyéndolo. (1265-1266)

Es el idioma fabulador de la literatura, cuya ventaja está, para Onetti, en su autonomía e intraducibilidad. Y sin embargo, quiero insistir en esto, se sugiere la posibilidad de dar con un sentido original de la imagen, a condición de que ese sentido primero, "intraducible", le sirva sólo al individuo aislado que se entrega a la experiencia estética. ${ }^{14}$

En síntesis, los comienzos narrativos de Onetti siempre ofrecen una imagen o conjunto de imágenes que incita a la interpretación. Sus relatos exploran símbolos, repositorios de un saber oculto, inarticulado, que todos, y en primer lugar los narradores, tratan de entender. Josefina Lúdmer expresa elocuentemente este concepto: "el narrador [de Onetti] es el que no sabe, narra porque no sabe" (124). Pero la comprensión, cuando se produce, es intransferible. Explicar es destruir la imagen en su tejido de posibilidades. El entendimiento es de carácter estético y su valor está más allá de los contenidos conjeturales que permite. Se disocian, de este modo, los términos de una crítica hermenéutica (entender y explicar) a la que esta literatura no deja equívocamente de alentar.

Por otra parte, si las imágenes que dan lugar a esta literatura evocan una tradición común, algo que todos creen comprender, hemos visto que estas son desestabilizadas frente a las expectativas de sentido (los prejuicios) que suscitan. La escena sobre la que se construye el relato proviene a menudo de otras literaturas, dando cuenta así de la tradición en la que se inscribe. He mencionado al pasar el aire faulknereano del personaje de doña Mina; pensaba en los paralelos e inversiones que muestra con Emily Grierson, la protagonista de "A Rose for Emily". ${ }^{15}$ Se encuentra en "Historia del caballero de la rosa y la virgen encinta que vino de Liliput" el mismo tipo de narrador (plural sociativo) y la misma gravitación de la comunidad con su curiosidad malsana y los prejuicios que vemos en el pueblo de la vieja Grierson. También nos retrotraen al mundo de Faulkner el carácter patricio de doña Mina, su cohorte de herederos 
desconocidos, la presencia de la criada negra, y el olor a encierro y naftalina de la casona convertida en museo. Una historia narrada por Onetti más de una vez que condiciona las expectativas "realistas" de aquellos lectores que entiendan demasiado rígidamente la herencia faulknereana.

Juan José Saer es muy claro respecto a los puntos de contacto y las diferencias entre las poéticas de ambos escritores ya que, si bien reconoce la importancia que tiene Faulkner para Onetti en el terreno de "las variaciones formales" y en cuanto al concepto de un conjunto narrativo formado por relatos a la vez tributarios e independientes, no ignora que

su deuda con Faulkner acaba ahí, puesto que la tentativa faulkneriana consiste en renovar la forma del relato para poder representar de manera más fiel una realidad que si bien no es lineal ni enteramente legible, no por eso deja de ser anterior y exterior al relato, en tanto que para Onetti son los problemas específicos de la representación, prescindiendo por completo del referente, o poniéndolo en un lugar secundario en el interior de su sistema narrativo, lo que constituye el objeto principal de sus búsquedas. (212)

Como se dice en algún momento del cuento que venimos de comentar, esta es "una vieja historia. Sólo que rara vez ... se ha dado de manera tan perfecta" (Onetti 1261).

MÍMESIS

Me referiré ahora a un tipo de imagen específico, tal como la brindan las fotografías del cuento "El álbum" (1953). Quiero pensar la incidencia de estos productos visuales en la narrativa de Onetti. ${ }^{16}$ La foto se presenta como un disparador de la ficción, trayendo un objeto que está dentro y fuera de su propio régimen de significación y temporalidad. Sobre esta doble condición nos invita a reflexionar el relato que, independientemente de la declaración final del narrador sobre el carácter "infamante" del realismo fotográfico, permite explorar las consecuencias estéticas del encuentro entre tales imágenes y la escritura. Diré por ahora que al ser convertidas en material narrativo las fotos pierden la naturaleza indexical, analógica, propia de su medio, dando lugar a una mímesis de calidad no ostensiva, adecuada a la verosimilitud de la ficción. También me interesa destacar que ante la falta de trascendencia y significación fotográficas (apunto a la presencia insidiosa del referente), la narración es llamada a "complementar" y enriquecer de sentido la escena visual, abriendo un plano (mágico) de comprensión refractario a la explicación. La prosecución de este vínculo entre imagen y lenguaje, que como recuerda Roger Chartier 
en su exégesis de Louis Marin son categorías irreductibles y de lógicas heterogéneas, resulta constitutiva de la poética de Onetti. ${ }^{17}$

El cuento en cuestión es un buen ejemplo de las tensiones que resultan de la búsqueda de dicho vínculo o escritura de la imagen. La trama da expresión al siguiente principio narrativo: el relato desprovisto de imágenes, sin referencia a la visión, no puede ser creído. "Sólo el 'ver personalmente' - escribe Lúdmer - puede compararse, en su estatuto de verdad ('ver para creer'), con la invención, con lo creado" (183-184). La ficción se cuenta siempre a partir de imágenes, pero quisiera recalcar que sobre estas se ha de llevar a cabo un trabajo de escritura, es decir, de invención. La mera copia es desechada como traición a la poética que, de acuerdo a mi lectura, confiere unidad a la obra. Las fotos que descubre Jorge Malabia, el joven narrador sobre cual Onetti traza en "El álbum" su retrato de artista, finalmente son condenadas porque muestran el referente exacto de cada una de las historias que la invariable y enigmática mujer de este cuento le ha estado contando. Revelan la no ficcionalidad de esas historias y anulan retrospectivamente el goce de haberlas escuchado.

Como es costumbre, en el comienzo de este cuento hay una visión:

La vi desde la puerta del diario, apoyado en la pared, bajo la chapa con el nombre de mi abuelo, Agustín Malabia, fundador ...

Era un domingo a la tarde, húmedo y caluroso en el principio del invierno. Ella venía del puerto o de la ciudad con la valija liviana de avión, envuelta en un abrigo de pieles que debía sofocarla, paso a paso contra las paredes brillosas, contra el cielo acuoso y amarillento, un poco rígida, desolada, como si me la fueran acercando, el atardecer, el río, el vals resoplado en la plaza por la banda, las muchachas que giraban emparejadas alrededor de los árboles pelados. (1273)

Después de esta imagen primera, la mujer es presentada a través de una serie de instantáneas (de pie en la esquina de la plaza de Santa María, contra el cartel de la cervecería, en un paisaje portuario y, por último, reflejada en el espejo del bar del hotel) que proclaman su inmovilidad y sugieren una posesión absoluta del tiempo. Anacrónica, ella transporta a Jorge a un tiempo fuera del tiempo que se revela como el de la "mythologie vécue" (Albouy 338). Como Sherazade y otros narradores excelsos, ella consumirá las horas a la dulce llama de los relatos que le cuenta a su joven amante en la cama de una habitación del hotel. ${ }^{18}$ Con la mención a Sherazade quiero subrayar no sólo el detenimiento temporal, sino también el simulacro y la invención; pues en su acercamiento a Jorge como en los encuentros siguientes es claro que la mujer va atrapándolo en un tejido de 
ficciones donde el deseo de escucharla mentir se superpone y termina prevaleciendo sobre los demás apetitos del adolescente.

La visión cede el lugar al arte de narrar que lleva a desentenderse de todo aquello que es ajeno a él. La autonomía de las ficciones condice con el despertar estético de Jorge, sintetizado en una frase del rey Lear que ha transcrito mal en una de las páginas de su cuaderno: "Why, thou wert better in thy grave that [sic] to answer with by [sic] uncovered body this extremity of the skies" (1277). ${ }^{19} 0$, como él mismo ha dicho antes, la falsedad de las historias escuchadas lo despojan de la verdadera realidad.

La imagen, entonces, es sólo un prólogo en espera de la "verdadera historia", constituida por los relatos de la mujer que, a su vez, como sabremos finalmente, han sido ideados a partir de las imágenes fotográficas compiladas en un álbum. Esta "empezó un anochecer helado, cuando oíamos llover y cada uno estaba inmóvil y encogido, olvidado del otro" (1279). Una historia fuera del tiempo y sin destinatarios, o por lo menos narrada en ignorancia de estos, que evoca una tormenta sobre el castillo de Aberdeen haciendo saber su gratuidad elemental. "No pude sospechar, ni siquiera cuando llegó la palabra Escocia, qué era lo que se estaba iniciando; la voz caía suave interrumpida encima de mi cara. Me explicó [la mujer] que sólo es lluvia la que cae sin utilidad ni sentido" (1280; énfasis mío).

Además de iluminar el vínculo complejo entre imagen y escritura, "El álbum" no deja dudas sobre el ars poetica de Onetti al parodiar otras escrituras de intención realista que se ven impelidas a comunicar y explicar. Un ejemplo de estas se encuentra fácilmente en las páginas del periódico local. En contrapunto con las historias de la mujer, el contraste de estilos no puede ser mayor:

Estaba seguro que la mujer había sido rechazada o disuelta por la imbecilidad de Santa María, simbolizada con exactitud por los artículos de mi padre: "Una verdadera afrenta, no trepidamos en decirlo, hecha por los señores concejales a los austeros y abnegados laborantes de las colonias circunvecinas que han fecundado con su sudor, generación tras generación, la envidiable riqueza de que disfrutamos." (1275)

Igualmente, llama la atención en este sentido la parodia de los prospectos medicinales que Jorge, mintiendo para poder acercarse a la mujer, dice tener que copiar para el viajante Maynard, otro huésped del hotel. El "estilo impersonal", "oscuro" y, sobre todo, "mesuradamente optimista" (1279) de los prospectos ofrece la contracara de la escritura onettiana. Ambos lenguajes, el del periódico y el de los productos farmacéuticos, 
fundan su credibilidad en un supuesto compromiso con la verdad. Contrariamente, tanto Jorge como la mujer mienten para ser creídos, afanándose en enlazar mímesis y poética. Se deduce pues que, en una literatura como la de Onetti donde se privilegia la instancia de la enunciación sobre el enunciado y el mundo representado es producto de una creación artística o invención, el enfoque hermenéutico sería el único pertinente. A condición de saber que dicho enfoque no conduce a la búsqueda de un mensaje o sentido específico, puesto por el autor y en espera de ser descubierto, sino a un proceso de constitución semántica y al descubrimiento de sentidos múltiples.

Como explica Ricoeur refiriéndose al legado de Aristóteles, la hermenéutica se acerca a la poética a través de lo que sería una imaginación productiva. Vale la pena de retener este argumento que redefine el concepto de mímesis, acentuando la disociación de

l'espace imaginaire de la fable de l'espace réel de l'action humaine ... Cet usage disjonctif, plutôt que référentiel, de la mimesis est tellement caractéristique de la poétique que c'est ce sens qui a prévalu dans la poétique contemporaine, lequel a retenu l'aspect structural du muthos et laissé tomber l'aspect référentiel de la fiction. (153)

Los diálogos entre Jorge y su amigo Tito ponen de manifiesto este aspecto del arte narrativo de Onetti. Es así que al elogiarle Tito un poema que describe Santa María, Jorge se defiende negándole todo valor estético: "Eso no es un poema [...] No es un poema, es la explicación de que tuve un motivo para escribir un poema y no pude hacerlo" (1283). Durante el fragmento de tiempo que cubre la historia de "El álbum", sólo la mujer posee la única poética posible, aquélla en que la ficción es asumida plenamente y olvida su supuesto antagonismo con la verdad. La ficción habita el presente que, de lo contrario, sólo tendría "rostros sin significado, retratos de caras ausentes, irrecuperablemente despojados de una realidad verdadera". Pocas veces, la poética de la mujer falla, desilusiona, como cuando parece imitar la escritura publicitaria, convencional (reconocible), de una revista extranjera (1281).

En la tarde última, antes de la desaparición de ella, Jorge completaría su educación estética. Reconoce, en ese momento, que el temor de perderla no se relaciona con la pérdida de sus historias, sus "peripecias y geografías" (1283), sino, más bien, "de una soledad que ... había habitado con una sensación de poder, con una clase de ventura que los días podrían ya nunca dar[le] ni compensar" (1284). El pasaje citado dice que el verdadero sentido es intransmisible, que únicamente puede servirle a un 
individuo aislado y que la creación y el goce estético son momentos de retorno a sí mismo y extrañamiento. Por ello, Jorge prescinde de formular "preguntas razonables" que puedan disipar el misterio de la mujer. Por ello, también, al escuchar en ese postrero encuentro la historia de una travesía tempestuosa sobre el Rin, puede descubrir y perdonar los indicios (el fracaso) de una realidad más que conocida:

Y las demás convicciones son dudosas: la intención de la sonrisa en la penumbra, la intensidad alarmante del frío, el amor tenebroso con que ella alargaba los detalles del viaje, sus ganas de suprimir lo esencial, de confundir los significados. Solo me dio, de todos modos, cosas que yo sabía de memoria: una balsa sobre un río, gente rubia e impávida, la siempre fallida esperanza de una catástrofe definitiva. (1284)

El diálogo que mantiene Jorge con Maynard, después de la partida de la mujer, sitúa "El álbum" entre los relatos de iniciación onettianos. Su evocación de Díaz Grey, narrador hegemónico del corpus-Onetti y verdadero padre espiritual de Jorge, también lo confirman. ${ }^{20}$ ¿Cómo devenir escritor? Esa es la pregunta que importa. Una vez solo, Jorge se dispone a "rehacer el mundo" (1285), a enriquecerlo desde la fábulas de la mujer. La experiencia ya ha comenzado a trabajarlo y le comunica el desencanto necesario para convertirse en narrador. El pasaje hacia esa condición es indicado por la recuperación del baúl que ella ha dejado como fianza de pago en el hotel. (No deja de ser significativo que para satisfacer los requisitos de ese pasaje Jorge deba desprenderse de su reloj, como si se quisiera indicar la entrada en otro régimen de temporalidad). La apertura del baúl revela el pasado de la mujer que, a partir de este momento, queda simbólicamente muerta. El hallazgo del álbum y otras pertenencias, en las que se destaca la suciedad, la vejez y el olor a encierro, adquiere el sentido de una exhumación. Las fotos provocan la emergencia del pasado, probando que la mujer ha habitado cada una de sus historias o, para recordar el célebre ensayo de Barthes, La chambre claire, que ella, "la muerta", ha estado efectivamente allí (120).

En cuclillas, envejecido, tratando de manejar la pipa con evidente soberbia, vi las fotografías en que la mujer - menos joven y más crédula a medida que iba pasando las páginas - cabalgaba en Egipto, sonreía a jugadores de golf en un prado escocés, abrazaba a actrices de cine en un cabaret de California, presentía la muerte en el ventisquero de Ruan, hacía reales, infamaba cada una de las historias que me había contado, cada tarde en que la estuve queriendo y la escuché. (1286)

En ese punto, Jorge aprende que la ficción se cuenta a partir de imágenes 
(principio constructivo de la narrativa onettiana), pero que estas deben permanecer secretas; sin entorpecer con su exceso analógico la oscuridad que corresponde a toda narración. Ya he mencionado a Marin y a Chartier, quienes analizan la relación entre imagen y lenguaje en términos de "irreductibilidad e intricación" (76). El siguiente pasaje de Pouvoirs de l'image echa luz sobre la poética de Onetti y sus motivaciones:

En esta irreductibilidad de lo visible a los textos - "visible" que es no obstante su objeto - los textos así glosados extraen, por una extraña referencialidad una capacidad renovada para acercarse a la imagen y sus poderes, como si la escritura y sus poderes específicos resultaran excitados y exaltados por ese objeto que, a causa de su heterogeneidad semiótica, se sustraería necesariamente a la todopoderosa influencia de aquéllos: como si el deseo de escritura (de la imagen) se ejercitara en realizarse "imaginariamente" deportándose fuera del lenguaje hacia lo que constituye, en muchos aspectos su reverso o su otro, la imagen. (Citado por Chartier 92)

Hay entre ambos términos una relación de atracción y cruce, pero sus dominios deben ser distinguidos. En su abundancia indicial, las fotografías de la mujer son declaradas oprobiosas, pues perturban la ficcionalidad narrativa. Estas confunden la realidad y la mímesis. La comprensión debe resultar de la imaginación. Sólo la experiencia estética, la experiencia de las formas, conduce a la posesión del sentido. En consideración de lo anterior, y para comenzar a pensar la actualidad de la poética de Onetti, he querido destacar el vínculo o "extraña referencialidad" que busca comunicar a la escritura el poder de las imágenes.

Reed College

NOTAS

1 Pocas obras críticas se han interesado en la relación que mantiene el arte narrativo de Onetti con lo visual. Sobresalen en este sentido los trabajos de Hugo J. Verani, quien ha analizado, específicamente, la influencia de la pintura en su obra; veánse Onetti: el ritual de la impostura (9-22) y su edición crítica del epistolario de Onetti con Payró. Sobre la función y valor semántico de la imagen, véanse José Pedro Díaz, Juan Carlos Mondragón y Aden Hayes.

2 De esos encuentros entre sueños y palabras, adviene en El pozo el relato de la cabaña de troncos. Habla Eladio Linacero, el narrador protagonista: "Quiero decir que es eso, nada más que eso. Lo que yo siento cuando miro la mujer 
desnuda en el camastro no puede decirse, yo no puedo, no conozco las palabras. Esto, lo que siento, es la verdadera aventura. Parece idiota, entonces, contar lo que menos interés tiene. Pero hay belleza, estoy seguro, en una muchacha que vuelve inesperadamente, desnuda, una noche de tormenta, a guarecerse en una casa de leños que uno mismo se ha construido, tantos años después, casi en el fin del mundo" (Onetti 25). Es importante notar que se trata de una imagen pre-verbal que, aunque alude a deseos o sentimientos, no tiene nada que la haga superior a otras. No obstante, hay allí una estética: la imagen que se vierte a la escritura permite recuperar ("tantos años después") un tiempo perdido.

3 Concuerdo con Roberto Ferro: "La interpretación es interminable, en la escritura de Onetti se exhibe que toda conceptualización de una verdad textual es inmediatamente excedida por el propio texto, que es un espacio sin límites y con un número siempre indefinido de alternativas de sentido" (383-384).

4 Viene a cuento recordar que, para esta rama de la hermenéutica, el entendimiento no es el resultado de una serie analítica que restituiría el sentido de la cosa dicha, sino más bien un modo que tiene el ser de estar en el mundo. Del mismo modo, las indagaciones que motiva la narrativa de Onetti desembocarían en un entendimiento que recusa toda comprensión lógica, dando lugar a un entendimiento en sí que, expresado en código gadameriano, es inseparable de la cosa comprendida.

5 Este componente de la narrativa onettiana (la trampa, el engaño) ha sido observado y comentado recurrentemente por la crítica; indicándose, sobre todo, el trabajo sobre el punto de vista como generador de ambigüedad y malentendido. En este sentido, véanse Fernando Ainsa (Las trampas; "Los posibles"), Hugo Verani, Josefina Lúdmer, Wolfang Luchting y Fernando Rodríguez Mansilla.

6 En un trabajo anterior, nos referíamos a esta disociación entre entender y explicar como un "reto hermenéutico" que obliga a "considerar de conjunto la dimensión simbólica presente en los relatos, aquellas escenas que motivan y ponen en funcionamiento el acto de la enunciación, y la conversión metafórica que revela parcialmente su sentido. Si indic[aba] el carácter parcial de tal esclarecimiento es porque hay en dichas escenas, como en toda configuración simbólica verdadera, un elemento no semántico, irreductible, que echa raíces en las 'profundidades de la experiencia humana' [Ricoeur, Teoría de la interpretación. Discurso y excedente de sentido ]" (Alonso 1027).

7 Agrego como dato significativo que el pequeño pueblo serrano, ubicable en las cercanías de la ciudad de Cosquín, provincia de Córdoba (Argentina), remite a otra Santa María. En la localidad de ese nombre funcionó hasta mediados del siglo pasado el sanatorio para tuberculosos que sirve de escenario a Los adioses. Creo que esto no había sido observado aún. 
8 Sobre los equívocos y las posibilidades interpretativas de esta nouvelle, Wolfang Luchting escribió un ensayo muy sonado, "El lector como protagonista de la novela de Onetti: Los adioses", en el que habría "descubierto" la identidad de una de las dos mujeres que visitan al hombre enfermo. Onetti saluda la sagacidad del crítico, pero le advierte acerca de la necesidad de dar "otra vuelta de tuerca" a su interpretación, dejando el texto abierto a otras conjeturas ("'Media vuelta"). Luchting vuelve a responder, pero esta vez de manera escéptica, recordando la inveterada tendencia a la trampa del narrador onettiano ("El lector").

9 Juan C. Mondragón, explica el recurso a la imagen como substituto al cual la escritura recurriría para suplir sus limitaciones semánticas, abriendo, "un sistema de significados paralelo a los poderes de la palabra ... como si el espacio de la pintura fuera el lugar elegido para la representación de la crisis personal y literaria que la novela [Dejemos hablar al viento] pone en funcionamiento: como si asistiéramos a un agotamiento de la escritura, a un intento de hallar otras modalidades expresivas" (citado en Verani, Onetti 19).

10 "Supongamos que todo está en orden - dijo el viejo Lanza -. Demasiado próxima a la perfección para ser una enana, demasiado segura y demagógica para ser una niña disfrazada de mujer" (Onetti 1249-1250).

11 La imagen tendría una dimensión simbólica que mantiene el sentido en suspenso, inarticulado. Contrariamente, el lenguaje o acto narrativo desempeña una función metafórica que haría comprensible la virtualidad semántica contenida en aquélla (véase Ricoeur, Teoría 82). Es este que produce el sentido y nos acerca a la comprensión. Ante una broma del viejo Lanza que nombra al protagonista como el caballero de la rosa, el narrador comenta la ocurrencia: "Nos pusimos a reír, separados de la pareja por el estruendo de la lluvia, creyendo que la frase servía para definir al muchacho y que ya empezábamos a conocerlo" (1251).

12 Asegura Guiñazú, por ejemplo, que él renunciaría a las matemáticas del interés ganancial "[a] cambio de escucharlos, de saber quiénes son, de saber quiénes y cómo somos nosotros para ellos" (Onetti 1268, cursiva mía).

13 En relación a dicho clímax, véase el pasaje en que el juez Canabal se ahoga en su propia risa, anticipando el goce de lo que supone el desengaño de la pareja y, frente a lo cual, Guiñazú comienza a revisar sus propios prejuicios: "Pero ya no me hace gracia -siguió Guiñazú -. La historia es demasiado cómica, monstruosamente cómica. Entonces, terminé por tomarla en serio, por desconfiar de lo que parece obvio. Por ejemplo, para despedirme, piense en el perro; dígame mañana por qué se lo dejó a él y no a las primas millonarias" (1270).

14 En una entrevista con María Esther Gilio, Onetti recuerda la historia del destinatario de Joyce, que es el mismo Joyce que está sentado del otro lado de 
la mesa, y juega con la idea que ésa también es su poética. La escritura como práctica vuelta hacia sí en la que ya no importa el contacto intersubjetivo. En relación a este carácter solipsista y refiriéndose al soliloquio final de Doña Mina, el caballero de la rosa nos deja otra certeza: "Pero estoy seguro de que no nos veía, esperando con toda la cara un ruido, una voz. Enderezada encima de las almohadas, deseando oír algo que no podíamos decirle nosotros. Y como la voz no llegaba, empezó a mover la cabeza, a inventarse un idioma desconocido para hablar con cualquier otro, tan velozmente que era imposible que la entendieran, anticipándose a las respuestas, defendiéndose de ser interrumpida". (1265)

15 El interés de Onetti por este cuento ha merecido igualmente la atención de Lúdmer; véase su análisis de "La novia (carta) robada (a Faulkner)” (189-211).

16 Para escribir esta sección de mi trabajo he vuelto a leer algunos textos canónicos sobre la fotografía; véanse Siegfried Kracauer, Susan Sontag, Ronald Barthes. Respecto a la cuestión del realismo fotográfico, acaso se note la gravitación de Sontag (muy especialmente, el capítulo de On Photography titulado "The Image-World") y de Kracauer. Igualmente, no dejé de pensar mientras escribía en el modo en que Barthes formula la paradoja que definiría la fotografía, a saber, la confluencia de un mensaje sin código - analógico, denotado - y un mensaje con código - estético, connotado - (Image 15-51). De otra manera, esto vuelve a encontrarse en los conceptos de studium y punctum, desarrollados en La chambre Claire.

17 Véase Chartier (91-94).

18 La frase en itálicas remite al ensayo de Walter Benjamin, "El narrador": "The storyteller: he is the man who could let the wick of his life be consumed completely by the gentle flame of his story" (108-109).

19 Se lee en el original: "Why, thou wert better in thy grave than to answer with thy uncovered body this extremity of the skies" (Shakespeare 115).

20 "Durante todo el día estuve pensando en el doctor Díaz Grey, imaginando que todo esto lo estaba haciendo por él, por el impreciso prestigio de la caballerosidad que él representaba en el pueblo, pequeño, bien vestido, desterrado, exagerando con ternura la renguera que apoyaba en el bastón" (Onetti 1286).

OBRAS CITADAS

A IN SA, FERnAN D 0. Las trampas de Onetti. Montevideo: Editorial Alfa, 1970.

—. "Los posibles de la imaginación". Juan Carlos Onetti. Ed. Hugo J. Verani. Madrid: Altea/Taurus/Alfaguara, 1987. 115-140.

ALB ouy, PIER Re. Mythographies. Paris: Librairie José Corti, 1976. 
A Lons O, DiEgo. "Incitación a la hermenéutica en la narrativa de Juan C. Onetti".

Revista Iberoamericana 78.241 (2012): 1027-1042.

BAR The S, Rolan D. Image, Music, Text. Trad. Stephen Heath. New York: Hill and

Wang, 1977.

—. La chambre claire. Paris: Éditions du Seuil, 1980.

Ben JA m In, walt e R. Illuminations. Ed. e Intr. Hannah Arendt. Trad. Harry Zohn.

New York: Schocken Books, 1969.

CHA R TIER, R o g E R. Escribir las prácticas. Foucault, De Certeau, Marin. Trad. Horacio

Pons. Buenos Aires, Ediciones Manantial, 2006.

dí AZ, José Pedro. "Sobre Juan Carlos Onetti". Juan Carlos Onetti. Ed. Hugo J. Verani.

Madrid: Altea/Taurus/Alfaguara, 1987. 92-114.

FER R O, R O B E R T O. Onetti/La fundación imaginada. La parodia del autor en la saga

de Santa María. Córdoba: Alción Editora, 2003.

GADAMER, HAN S-GE ORG. Verdad y método. Fundamentos de una hermenéutica

filosófica. Salamanca: Sígueme, 1977.

GILIO, MA RÍ A ESTHER. Estás acá para creerme. La historia de mis entrevistas con

Juan Carlos Onetti. Montevideo: Cal y canto, 2009.

HAYES, ADEN w. "Onetti's El pozo: Imagination and Image". Juan C. Onetti. Novelas cortas. Coord. Daniel Balderston. Poitiers: Centre de Recherches LatinoAméricaines - Archivos, 2009. 848-857.

KRACAUER, SIEGFRIED. La fotografía y otros ensayos: el ornamento de la masa 1.

Barcelona: Gedisa, 2007.

LUCHTING, WOLFANG A. "El lector como protagonista de la novela de Onetti: Los adioses". Juan C. Onetti. Novelas cortas. Coord. Daniel Balderston. Poitiers:

Centre de Recherches Latino-Américaines - Archivos, 2009. 731-739.

—. “ ¿Esse acaso ya no Est Percipi? El triste papel de la epistemología en Los adioses de Juan C. Onetti”. Juan C. Onetti. Novelas cortas. Coord. Daniel Balderston. Poitiers: Centre de Recherches Latino-Américaines - Archivos, 2009. 787-793. LÚ D MER, JOSEF INA. ONET TI. Los procesos de construcción del relato. Buenos Aires: Sudamericana, 1977.

MONDRA Gón, JuAn CARlos. "Las ideas estéticas del comisario Medina”. Río de la Plata 25 (2003): 181-192.

onetti, juan Carlos. Obras completas. México D.F.: Aguilar, 1970.

- . “'Media vuelta' de tuerca”. Juan C. Onetti. Novelas cortas. Coord. Daniel Balderston. Poitiers: Centre de Recherches Latino-Américaines - Archivos, 2009. 739.

RANCIÈRE, JACQUEs. Figuras de la historia. Buenos Aires: Eterna Cadencia, 2013.

Ri C OEUR, PAu L. "Rhétorique - Poétique - Herméneutique". De la métaphysique à la rhétorique: essais à la memoire de Chaïm Perelman avec un inédit sur la logique. Bruxelles: Éditions de l' Université de Bruxelles, 1986. 143-155. 
-. Teoría de la interpretación. Trad. Graciela Monges Nicolau. México D.F./Buenos Aires/Madrid: Siglo XXI Editores, 1995.

RODRÍGUEZ MANSILLA, FERNAND O. "Un narrador cínico y el amor: 'Esbjerg, en la costa"'. Itinerarios 7 (2008): 166-174.

SAER, JUA N J o SÉ. Trabajos. Buenos Aires: Grupo Editorial Planeta S.A.I.C./Seix Barral, 2005.

Sinn o T, e duard o. "Introducción". Aristóteles. Poética. Buenos Aires: Colihue, 2009. VII-XLII.

SOnTAG, susAn. On Photography. New York: Macmillan, 2011.

veran I, hugo J. Onetti: el ritual de la impostura. Montevideo: Ediciones Trilce, 2009.

-. "Cartas de un joven escritor". Juan C. Onetti. Cartas de un joven escritor. Correspondencia con Julio E. Payró. Ed. H. J. Verani. Montevideo: Ediciones Trilce, 2009. 11-26. 